\title{
The Effect of Industrial Revolution 4.0 on Social Entrepreneurship in Malaysia; Evidence of Neurocomputing Analysis on Contributing Factors Towards Tertiary Level Students' Readiness
}

\author{
Norlinda Mohd Rozar ${ }^{\# 1}$, Mohd Nazri Zakaria ${ }^{\# 2}$, Muhammad Ashlyzan Razik ${ }^{\# 3}$, \\ Aisyah Bahiah Aidul Bahrein ${ }^{\# 4}$, Saadi bin Ahmad Kamaruddin ${ }^{* 5}$ \\ \# Universiti Malaysia Kelantan, Faculty Business and Entrepreneuship, Kampus Kota, Karung Berkunci 36, \\ Pangkalan Chepa, 16100 Kota Bharu, Kelantan, MALAYSIA. \\ ${ }^{1}$ lindarozar78@gmail.com \\ ${ }^{2}$ mnazri.z@umk.edu.my \\ 3 ashlyzan@umk.edu.my \\ ${ }^{4}$ aishah_bahiah@yahoo.com \\ *Department of Business Studies, Faculty of Business, Economics and Accounting, ELM Business School, \\ HELP University, No. 15, Jalan Sri Semantan 1, Off Jalan Semantan, Bukit Damansara, 50490 Kuala Lumpur, \\ Malaysia \\ 5 adi8585@yahoo.com
}

\begin{abstract}
The world is growing quick because of the innovative insurgency that incredibly impacts our method for living and the conduct of the two people and associations. Industry 4.0 (otherwise called Fourth Industrial Revolution) shows itself in the manner in which information changes, advancements are robotized and digitized, and what we currently call the Internet of things (IoT). Instruction suppliers is presently taking a gander at eight $\mathbf{4 . 0}$ transformational needs by looking at the customary and old economy, and the troublesome and new economy. Beforehand the economy was assets centered, the new economy is learning serious; in the past it was work escalated, now it requires high gifted ability; and once requiring control, the new economy requests joint effort. In this research, artificial neural network is adapted to rank the importance of contributing factors which influence the students' readiness toward social entrepreneurship and innovation among Malaysian undergraduate students. A population of N=127 undergraduate students of Bachelor of Social Entrepreneurship were taken. The models is highly significant at $\mathrm{p}=\mathbf{0 . 0 0 0}(\mathrm{RE}=\mathbf{0 . 7 9 4}$ ) with $13-4-1$ configurations respecting to input-hidden-output nodes. Eventually, it is found that the top five most essential factors which influence students' readiness toward social entrepreneurship and innovation are moral obligations, self-efficacy, prior knowledge, career adaptability and empathy accordingly. As a conclusion, this research parallel to the Economic Transformation Programme enroute to the 2050 National Transformation which is the country's vision of being among the top countries in the world in economic development, citizen well-being and innovation.
\end{abstract}

Keyword - Industrial Revolution 4.0, Social Entrepreneurs and Innovation, Tertiary, Undergraduates, Malaysia.

\section{INTRODUCTION}

T Industry 4.0 is identified with what is known as the "savvy manufacturing plant" (Dutton, 2014). In a brilliant industrial facility, a virtual duplicate of the physical world and decentralized basic leadership can be produced (Buhr, 2015). Additionally, physical frameworks can participate and speak with each other and with people progressively, all empowered by the IoT and related administrations.

The discussion about Industry 4.0 and its worldwide effect is becoming quickly because of serious dialogs about digitization, the Internet of things, and savvy learning and frameworks (Friess and Ibanez, 2014; Vermesan et al., 2014). The discussion is driven by vulnerability about the most ideal approach to misuse the quick pace of mechanical advancement to enhance different parts of human life.

The idea of Industry 4.0 has its inceptions in Germany and has been perceived by other driving mechanical countries, despite the fact that it is known as "Associated Enterprise" in the United States and the "Fourth Industrial Revolution" in the United Kingdom. Regardless, Industry 4.0 is based on three going before innovative changes: steam control, which was the transformative power of the nineteenth century; power, which changed a significant part of the twentieth, and the time of the PC start of 1970s (Cordes and Stacey, 2017). We 
expect that the effect of Industry 4.0 will be more significant, irreversible, and substantially more fast than the past three ages. The high development in the request of innovations (fundamentally data and correspondence advances) by mechanical firms can fuel the eventual fate of Industry 4.0 and may result in positive overflow impacts to various regions.

The expression "Business 4.0" was begun in 2011 at the Hanover Fair in Germany as a procedure to relieve the expanding rivalry from abroad and to separate German and European Union ventures from other universal markets (Pascall, 2017). Additionally, the German government tried to utilize wise observing underway procedures so as to help basic leadership and machine support to decrease expenses and increment the intensity of German enterprises. With a specific end goal to comprehend what is implied by Industry 4.0, PwC (2017) proposed a system, which likewise was received by the Flemish Government. The possibility of the system emerged by requesting that driving organizations decide their needs among a gathering of ideas. Brilliant frameworks, people in Industry 4.0, shrewd creation, and relationship building abilities were recognized as the most astounding needs.

Acatech (2014) portrayed Industry 4.0 as the IoT: information and administrations that will change future generation, coordinations, and work forms. This implies the advancement of the IoT has gone past Internetassociated applications lately with the joining of various advances, for example, machine learning, installed frameworks, and remote association. The European Research Cluster on the Internet of Things (IERC) (Vermesan et al., 2009) expressed that the IoT is " an incorporated piece of Future Internet and could be characterized as a dynamic worldwide system foundation with self-arranging capacities in view of standard and interoperable correspondence conventions where physical and virtual 'things' have personalities, physical traits, and virtual identities and utilize insightful interfaces, and are consistently coordinated into the data organize." IERC included that "things" in the IoT "are relied upon to end up dynamic members in business, data and social procedures where they are empowered to associate and convey among themselves and with the earth by trading information and data 'detected' about the earth, while responding independently to the 'genuine/physical world' occasions and affecting it by running procedures that trigger activities and make administrations with or without coordinate human intercession". Vermesan et al. (2014) affirmed that the principle objective of the IoT is to "empower things to be associated whenever, wherever, with anything and anybody in a perfect world utilizing any way/organize and any administration".

\section{RELATED LITERATURES}

Industry 4.0 is exceptionally associated with development. In the most recent decade, advancement added encourage fixings to the blend - versatile, cloud, web-based life, and enormous information - which together may fabricate an immaculate advantageous interaction, make new idea for the industrialization procedure, and move the market into new period of rivalry and separation of items (Geiger and Sá, 2013). Industry 4.0 speaks to a move toward an advancement based economy with information, information, and the IoT as focal ideas. This will influence the present structure, markets, and business procedures of the modern age and prepare to another period of digitization, "more quick witted" systems administration of creation frameworks, and interlinked business forms.

A large portion of the ongoing writing about the Fourth Industrial Revolution centers around the mechanical advancement nature of Industry 4.0. There is worry about whether the quick development in innovative improvement and digitization is leaving a positive effect on the people and society (Luppicini, 2012). In this manner, while considering how mechanical advancement can be misused to take care of society issues, we should likewise see mechanical developments through a social point of view.

Industry 4.0 spoken to by the high development in innovation empowered stages has disturbed the current business structures and made better approaches for expending merchandise through the blend of interest and supply. It likewise sorts out how individuals function and expend, it changes the idea of benefits, and it influences how information is gotten and controlled. Also, it brings down the obstructions for individuals and organizations to contribute and make riches, which thus adjusts the encompassing individual and expert situations (Schwab, 2015). 


\section{DATA BACKGROUND}

A population of $\mathrm{N}=127$ undergraduate students of Bachelors of Social Entrepreneurship at University Malaysia Kelantan were taken. The descriptive statistics can be seen in Table 1.

TABLE I. Descriptive Statistics

\begin{tabular}{|c|c|c|c|}
\hline & Mean & Std. Deviation & N \\
\hline Readiness Intention & 4.6037 & .38657 & 127 \\
\hline Gender & 1.7008 & .45973 & 127 \\
\hline Ethnic Group & 1.4331 & .84130 & 127 \\
\hline Age & 1.2756 & .55887 & 127 \\
\hline Current Study Program & 2.1969 & .59147 & 127 \\
\hline Current Year of Study & 2.1024 & .79517 & 127 \\
\hline Field of Study & 1.0866 & .28238 & 127 \\
\hline Empathy & 4.2913 & .58304 & 127 \\
\hline Moral Obligation & 4.4606 & .54045 & 127 \\
\hline Self Efficacy & 4.0039 & .59760 & 127 \\
\hline Social Support & 3.9764 & .57858 & 127 \\
\hline Prior Knowledge & 3.7717 & .79246 & 127 \\
\hline Entrep Alertness & 3.8928 & .58576 & 127 \\
\hline
\end{tabular}

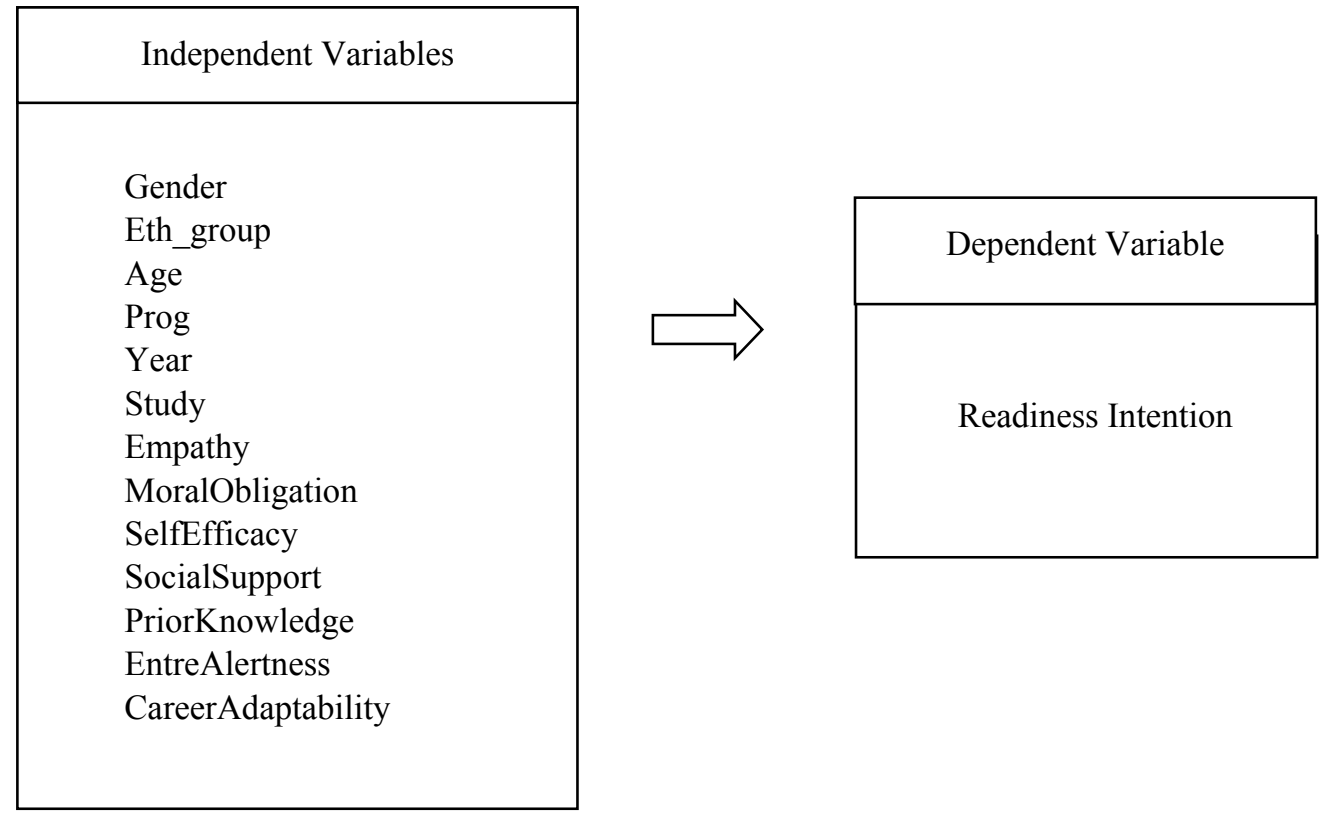

Fig.1. Theoretical Framework

\section{Methodology}

In this research, we adapted two-layer neural network, with tangis transfer function in the first layer and purelin transfer function at the second layer. Trainscg is the training function used in this research, with MSE equals to 0.0 as the criterion function. The data are partitioned into three different sets which are training $(70 \%)$, validation (30\%) and testing (30\%) sets. A nonlinear model that contains more than one predictor variable neural network is developed in this research. Fig.1. illustrates the theoretical framework of this research in order to achieve the main objective. The following model is a neural network model with 13 predictor variables, $\beta 1$, $\beta 2, \beta 3, \beta 4, \beta 5, \beta 6, \beta 7, \beta 8, \beta 9, \beta 10, \beta 11, \beta 12$, and $\beta 13$. 


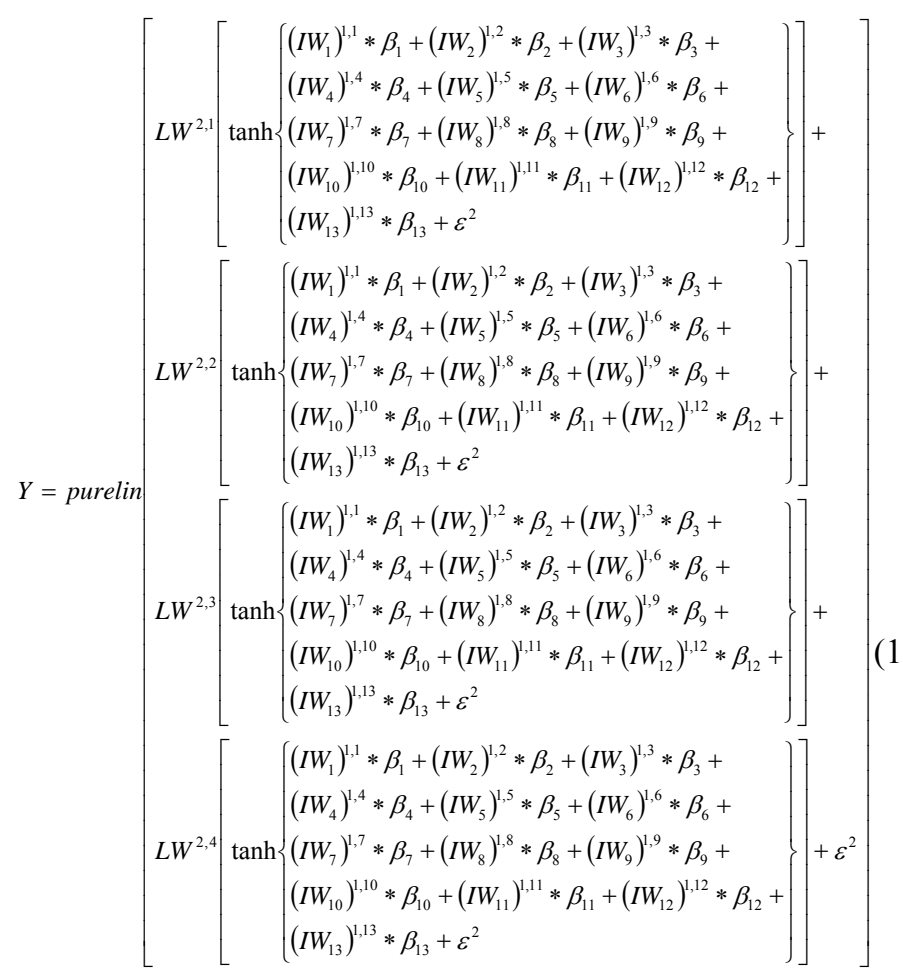

In this research, the general model is

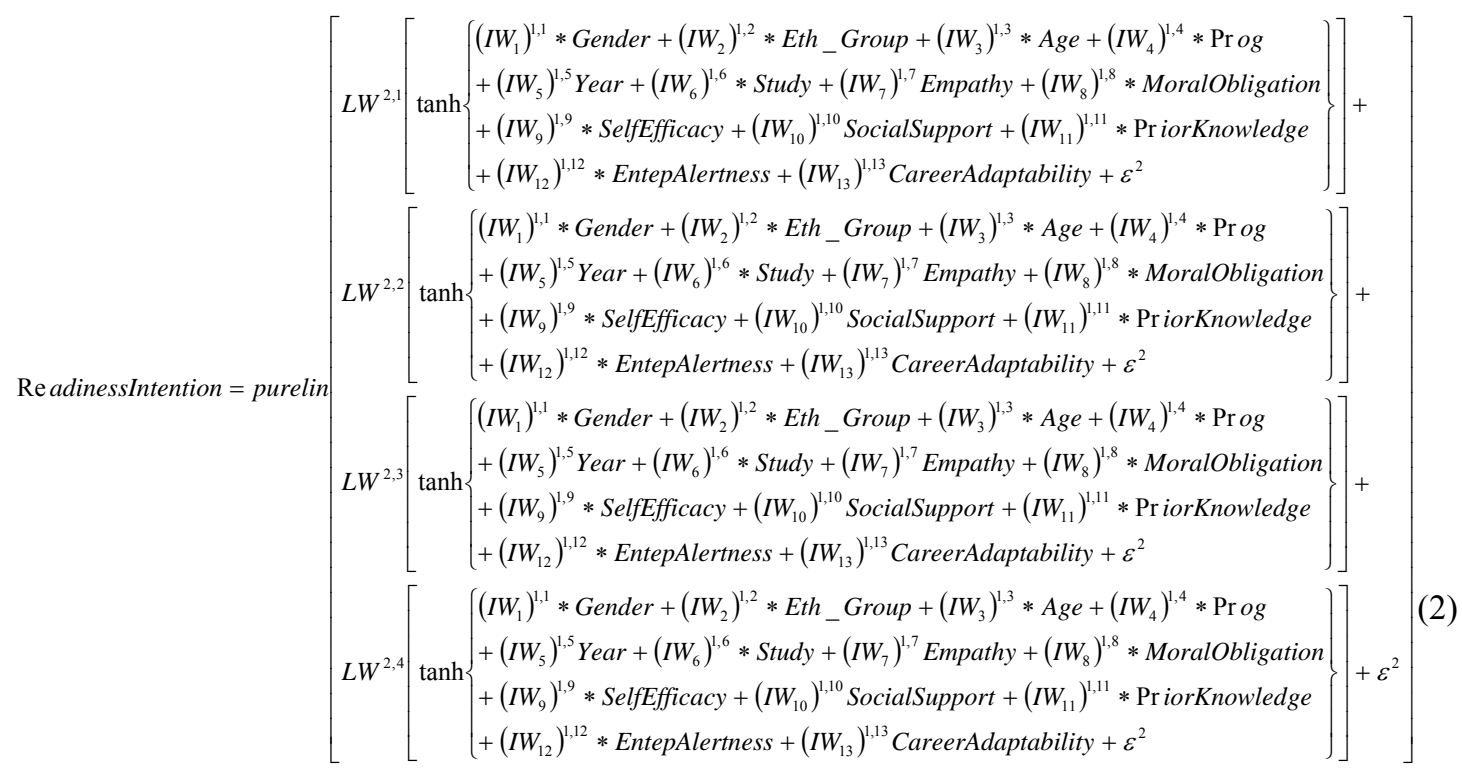

The final model will include only the significant predictors to describe Total Mark. Table 2 also represents the variables used in this research as well as the explanations of each variable. 
TABLE II. Variables of Interest

\begin{tabular}{|c|c|c|}
\hline Dependent Variable & Notation & Type \\
\hline Readiness Intention & Readiness Intention & Continuous \\
\hline Independent Variables & Notation & Type \\
\hline Gender & Gender & Catagorical \\
\hline Ethnic Group & Eth_Group & Catagorical \\
\hline Age & Age & Continuous \\
\hline Current Study Program & Prog. & Catagorical \\
\hline Current Year of Study & Year & Continuous \\
\hline Field of Study & Study & Catagorical \\
\hline Empathy & Empathy & Continuous \\
\hline Moral Obligation & Moral Obligation & Continuous \\
\hline Self-Efficacy & Self Efficacy & Continuous \\
\hline Social Support & Social Support & Continuous \\
\hline Prior Knowledge & Prior Knowledge & Continuous \\
\hline Entrepreneurship Alertness & Entrep Alertness & Continuous \\
\hline Career Adaptability & Career Adaptability & Continuous \\
\hline
\end{tabular}

\section{RESUlT}

Based on Table 3, in the preprocessing part, the data were divided into two sets; training and testing. Training set consist of $68.5 \%(87 / 127)$ of the overall data, while testing sets comprises of $31.5 \%(40 / 127)$ of the overall data, $\mathrm{N}=127$. There were no missing values recorded.

TABLE III. Case Processing Summary

\begin{tabular}{|c|c|c|c|}
\hline \multicolumn{2}{|c|}{ Data Partitioning } & N & Percent \\
\hline \multirow{2}{*}{ Sample } & Training & 87 & $68.5 \%$ \\
\cline { 2 - 4 } & Testing & 40 & $31.5 \%$ \\
\hline \multicolumn{2}{|c|}{ Valid } & 127 & $100.0 \%$ \\
\hline \multicolumn{2}{|c|}{ Excluded } & 0 & \\
\hline \multicolumn{2}{|c|}{ Total } & 127 & \\
\hline
\end{tabular}

Table 4 shows the overall network information. The covariates to the network were Gender, Ethnic Group, Age, Current Study Program, Current Year of Study, Field of Study, Empathy, Moral Obligation, Self-Efficacy, Social Support, Prior Knowledge, Entrepreneur Alertness and Career Adaptability. These 13 covariates were the inputs nodes in the input layer of the network. This network consists of only one hidden layer, with four nodes. The activation function from input layer to hidden layer was hyperbolic tangent. The target of the network is Readiness Intention, where the activation function from hidden layer to output layer was identity (purelin). The default error function in backpropagation neural network was based on sum of squares (SSE). To simplify, the configurations of this network was 13-4-1. The network architecture can be referred in Figure 2. 
TABLE IV. Network Information

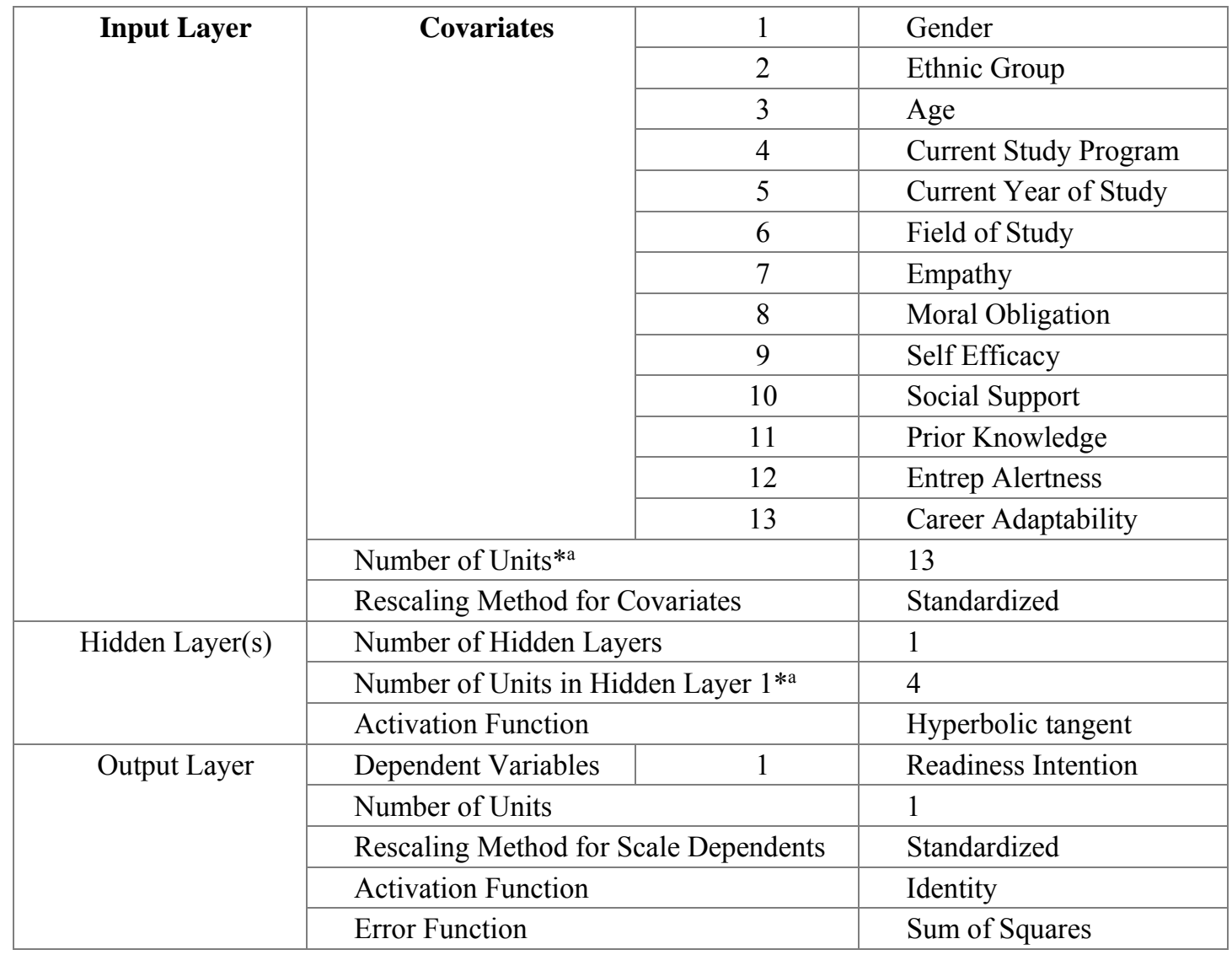

*a Excluding the bias unit

Table 5 shows the model summary of both training and testing sets. For this particular network, the sum of squares of testing sets was 25.358, with relative error equals to 0.794 . On the other hand, the sum of squares for training set was 43.689 , with relative error equals to 1.016 . It can be said that in any network, testing set should be the reference. The relative error was 79.4 percent which was quite high. Therefore, it is firmly believe the network error can be reduced by changing the network settings, in order to improve the network performance.

TABLE V. Model Summary

\begin{tabular}{|l|l|l|}
\hline \multirow{4}{*}{ Training } & Sum of Squares Error & 43.689 \\
\cline { 2 - 3 } & Relative Error & 1.016 \\
\cline { 2 - 3 } & Stopping Rule Used & 1 consecutive step(s) with no decrease in error ${ }^{\mathrm{a}}$ \\
\cline { 2 - 3 } & Training Time & $0: 00: 00.04$ \\
\hline \multirow{2}{*}{ Testing } & Sum of Squares Error & 25.358 \\
\cline { 2 - 3 } & Relative Error & .794 \\
\hline
\end{tabular}

Dependent Variable: Readiness Intention 
ISSN (Print) : 2319-8613

a. Error computations are based on the testing sample.

Synaptic Weight $>0$ Synaptic Weight $<0$

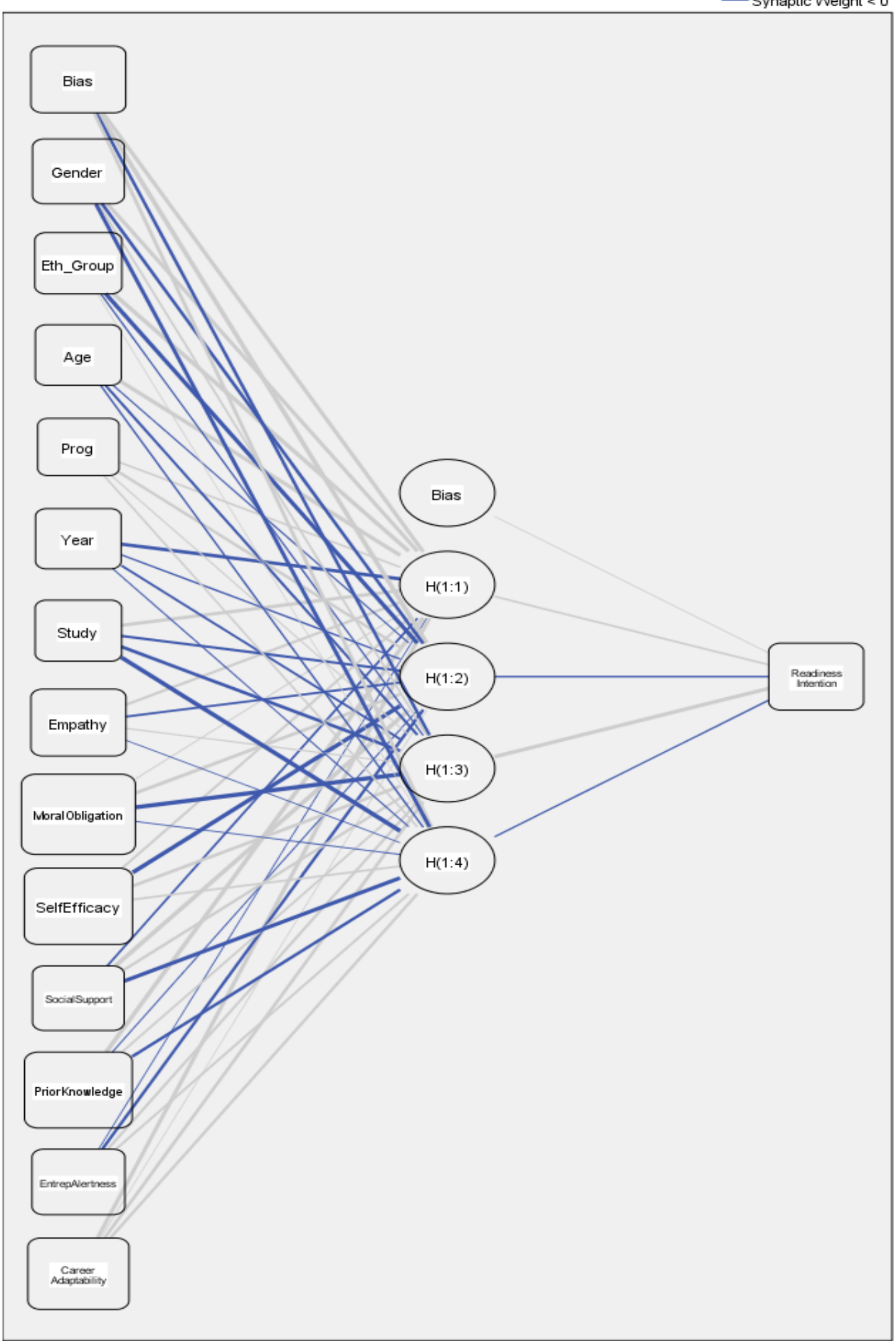

Hidden layer activation function: Hyperbolic tangent

Output layer activation function: Identity

Fig. 2. Network Architecture 


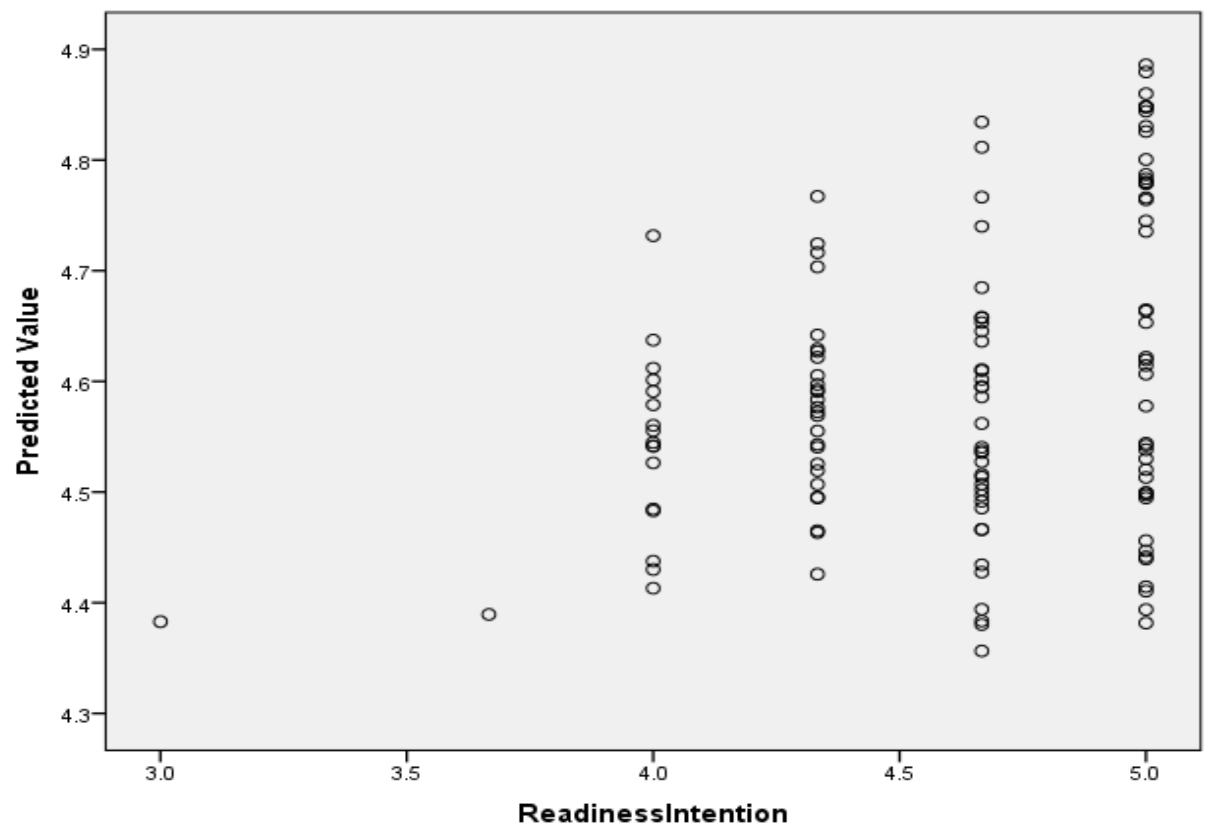

Fig.3.Standardized Residuals

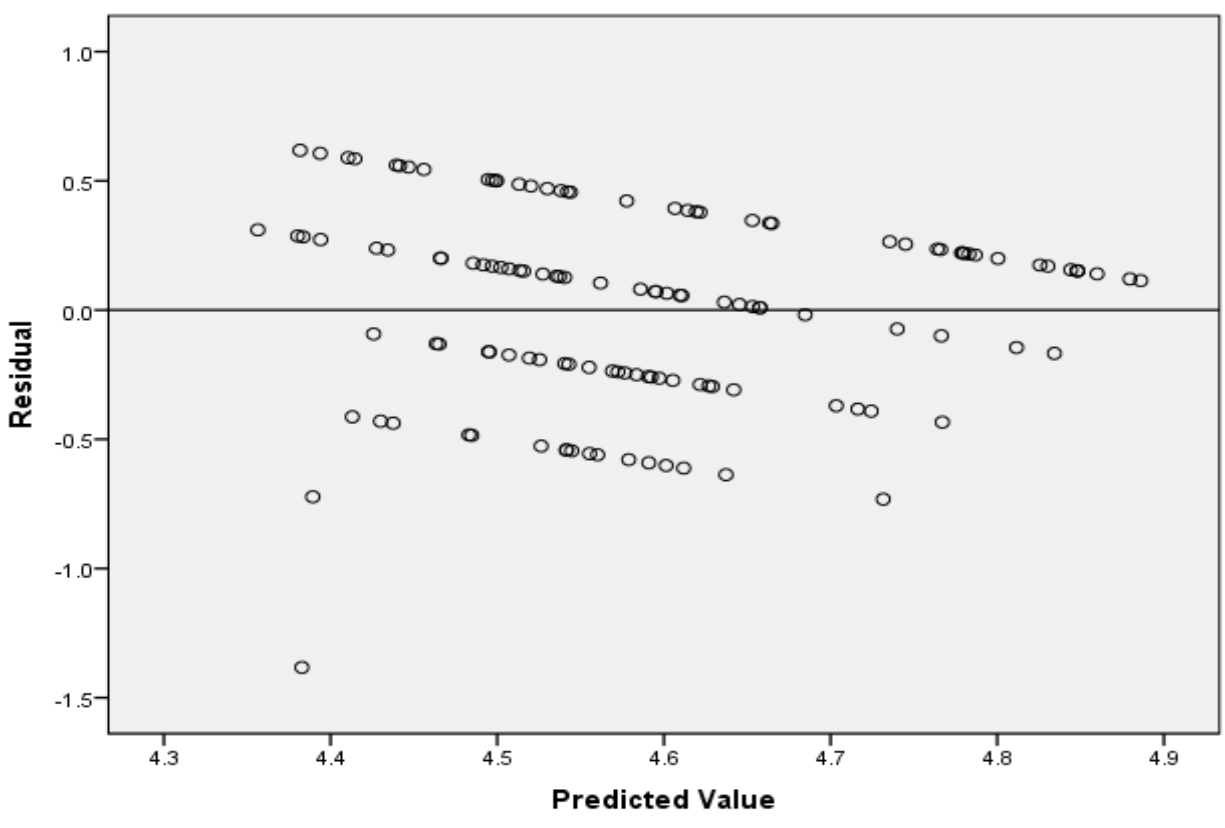

Dependent Variable: ReadinessIntention

Fig.4. Distribution of Standardized Residuals 
TABLE VI. Independent Variable Importance

\begin{tabular}{|c|c|c|}
\hline Independent Variables & Importance & Normalized Importance \\
\hline Gender & .066 & $41.9 \%$ \\
\hline Ethnic Group & .046 & $29.2 \%$ \\
\hline Age & .042 & $26.4 \%$ \\
\hline Current Study Program & .022 & $14.0 \%$ \\
\hline Current Year of Study & .040 & $25.2 \%$ \\
\hline Field of Study & .044 & $27.7 \%$ \\
\hline Empathy & .079 & $50.2 \%$ \\
\hline Moral Obligation & .157 & $100.0 \%$ \\
\hline Self Efficacy & .134 & $84.9 \%$ \\
\hline Social Support & .065 & $41.4 \%$ \\
\hline Prior Knowledge & .132 & $83.6 \%$ \\
\hline Entrep Alertness & .070 & $44.8 \%$ \\
\hline Career Adaptability & .104 & $66.3 \%$ \\
\hline
\end{tabular}

Figure 3 and Figure 4 show the standardized residuals and the distribution of standardized residuals respectively. It is found that the top five most essential factors which influence students' readiness toward social entrepreneurship and innovation are moral obligations (100\%), self-efficacy (84.95), prior knowledge (83.6\%), career adaptability (66.3\%) and empathy (50.2\%) accordingly. The parameter estimates can be referred in Table 7.

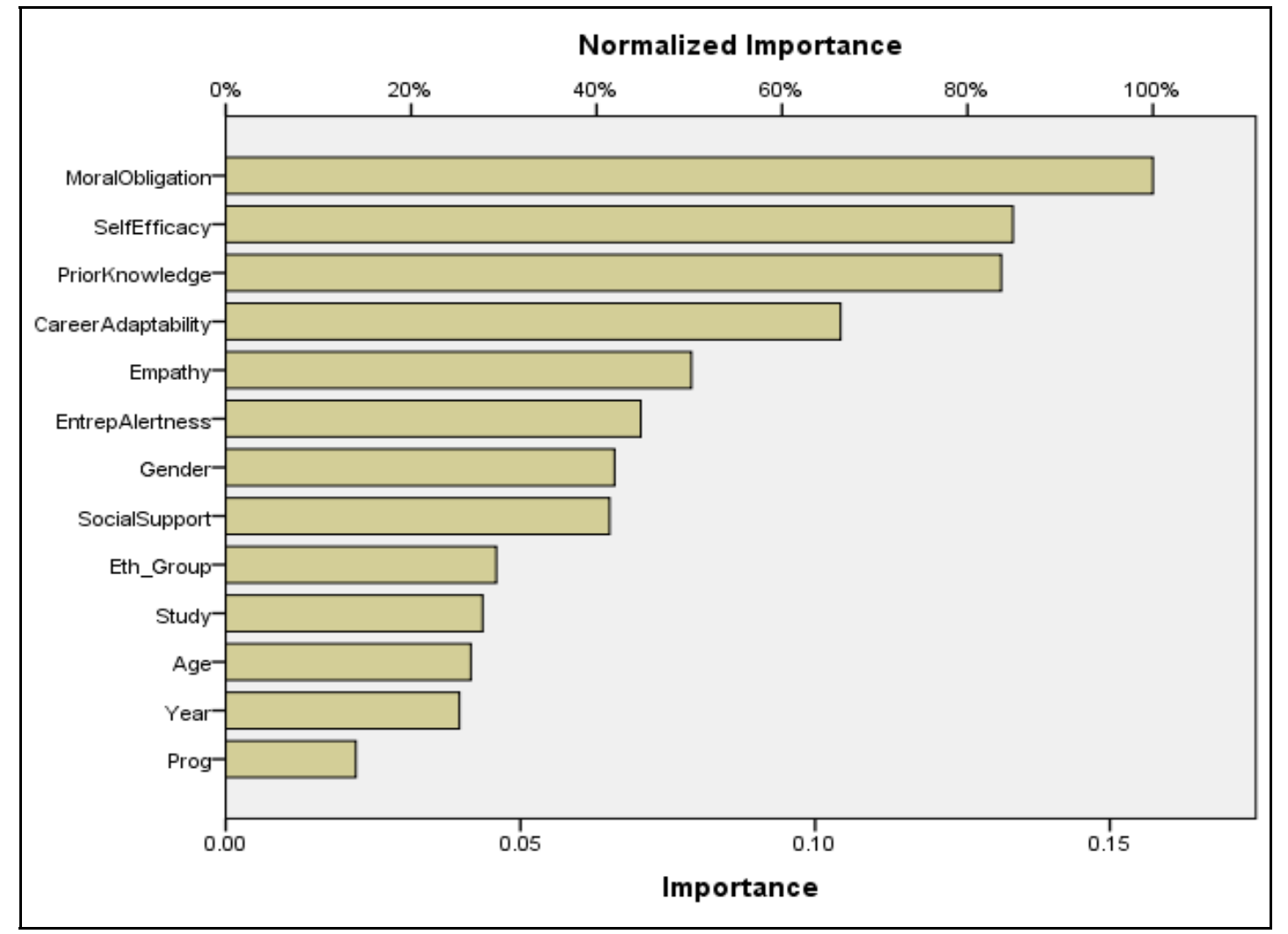

Fig.4.Normalized Importance of the Covariates 
TABLE VII. Parameter Estimates

\begin{tabular}{|c|c|c|c|c|c|c|}
\hline \multicolumn{2}{|r|}{ Predictor } & \multicolumn{5}{|c|}{ Predicted } \\
\hline & & \multicolumn{4}{|c|}{ Hidden Layer 1} & \multirow{2}{*}{$\begin{array}{c}\text { Output Layer } \\
\text { Readiness } \\
\text { Intention }\end{array}$} \\
\hline & & $\mathrm{H}(1: 1)$ & $\mathrm{H}(1: 2)$ & $\mathrm{H}(1: 3)$ & $\mathrm{H}(1: 4)$ & \\
\hline \multirow[t]{14}{*}{ Input Layer } & (Bias) & .428 & .486 & -.291 & .334 & \\
\hline & Gender & .375 & -.321 & .151 & -.368 & \\
\hline & Eth_Group & .452 & -.451 & -.121 & .004 & \\
\hline & Age & .447 & -.104 & -.236 & -.129 & \\
\hline & Prog & .137 & .289 & .102 & .137 & \\
\hline & Year & -.355 & -.123 & -.201 & -.082 & \\
\hline & Study & .342 & -.250 & -.334 & -.487 & \\
\hline & Empathy & .258 & -.210 & .106 & -.027 & \\
\hline & Moral Obligation & .075 & .341 & -.491 & -.061 & \\
\hline & Self Efficacy & .230 & -.473 & .327 & .190 & \\
\hline & Social Support & -.171 & .473 & .273 & -.451 & \\
\hline & Prior Knowledge & .466 & -.077 & .194 & -.290 & \\
\hline & Entre Alertness & -.031 & -.287 & .239 & .226 & \\
\hline & Career Adaptability & .427 & .010 & .327 & .286 & \\
\hline \multirow{5}{*}{$\begin{array}{l}\text { Hidden } \\
\text { Layer } 1\end{array}$} & (Bias) & & & & & .018 \\
\hline & $\mathrm{H}(1: 1)$ & & & & & .167 \\
\hline & $\mathrm{H}(1: 2)$ & & & & & -.132 \\
\hline & $\mathrm{H}(1: 3)$ & & & & & .433 \\
\hline & $\mathrm{H}(1: 4)$ & & & & & -.122 \\
\hline
\end{tabular}

\section{CONCLUSION}

As a conclusion, the main objective of the research has been successfully achieved. The configuration of the network adapted was 13-4-1, with hyperbolic tangent and purelin activation functions in hidden layer and output layer respectively. It is expected that optimal results can be achieved by changing the network settings, in order to improve the network performance. In the near future, several artificial neural network models will be compared in order to find the optimal model for the dataset used in this research in order to avoid the overfitting problem.

In the meanwhile, it is believed that the results are only applicable to Malaysian undergraduate students at public universities. However, this is just a preliminary studies. They context should be applied to all public universities in Malaysia. In future endeavours, this result should be extended to all private universities in Malaysia as well, before we can make a general conclusion upon undergraduate students' entrepreneurship readiness of Malaysian context.

To stay pertinent, tertiary institutions in Malaysia need to give understudies the experience of working inside complex and information rich frameworks. Through the program, understudies effectively connect with the business to do joint activities. Such communications enable understudies to shape associations with the business early, which gives them a head begin, even before they graduate.

\section{ACKNOWLEDGMENT}

This research was supported by Research and Innovation of University Malaysia Kelantan. We thank Mohd Nazri Zakaria (Senior Lecturer and Deputy Dean of Students Development and Entrepreneurship) and Muhammad Ahslyzan Razik (Senior Lecturer) at the Faculty of Entrepreneurship and Business of University Malaysia Kelantan for sharing their pearls of wisdom during the course of this research who provided insight and expertise that greatly assisted the research. We thank our colleagues from the Faculty Business and Entrepreneurship of University Malaysia Kelantan, and Faculty of Computer and Mathematical Sciences of University Technology MARA for assistance with the particular technique and the methodology and for comments that greatly improved the manuscript 


\section{REFERENCES}

[1] Acatech, Partitionierung und Transmutation nuklearer Abfälle - Chancen und Risiken in Forschung und Anwendung, acatech POSITION, H. Utz Verlag, Munich, 2014.

[2] Buhr, D. Social Innovation Policy for Industry 4.0. Tübingen, Germany: Eberhard Karls University of Tübingen, 2015.

[3] Cordes, F., \& Stacey, N. Is UK Industry Ready for the Fourth Industrial Revolution? Boston, MA: The Boston Consulting Group, 2017.

[4] Dutton, H. W. Putting Things to Work: Social and Policy Challenges for the Internet of Things. Info, 16(3): 1-21, 2014.

[5] Friess, P., \& Ibanez, F. 2014. Putting the Internet of Things Forward to the Next Level. In O. Vermesan \& P. Friess (Eds.), Internet of Things Applications - From Research and Innovation to Market Deployment: 3-6. Gistrup, Denmark: Rivers Publishers.

[6] Geiger, R., \& Sá, C. Tapping the Riches of Science: Universities and the Promise of Economic Growth. Cambridge, MA: Harvard, 2013.

[7] Luppicini, R. Ethical Impact of Technological Advancements and Applications in Society. Hershey, PA: Information Science Reference, 2012.

[8] Pascall, T. Innovation and Industry 4.0. Disruption, April 19, 2017. Accessed November 1, 2017.

[9] Phills, J. A. Jr., Deiglmeier, K., \& Miller, D. T. Rediscovering Social Innovation. Stanford Social Innovation Review, 6(4): 34-43, 2008.

[10] PwC. 2017. Industry 4.0: The Current State of Play in Flemish Manufacturing. Press Release. PwC, March 31, 2017. Accessed November 1, 2017.

[11] Rifkin, J. The Zero Marginal Cost Society: The Internet of Things, the Collaborative Commons, and the Eclipse of Capitalism. New York: St. Martin's Press,2014.

[12] Schwab, K. The Fourth Industrial Revolution. Geneva: World Economic Forum,2015.

[13] Vermesan, O., Friess, P., Guilleman, P., Gusmeroli, S., Sundmaeker, H., Bassi, A., Jubert, I. S., Mazura, M., Harrison, M. Eisenhauer, M., \& Doody, P. Internet of Things - Strategic Research Roadmap. Brussels: European Commission, Information Society and Media DG; Cluster of the European Research Projects on the Internet of Things (CERP-IoT),2009.

[14] Vermesan, O., Friess, P., Guillemin, P., \& Sundmaeker, H. Internet of Things Strategic Research and Innovation Agenda. In O. Vermesan \& P. Friess (Eds.), Internet of Things Applications - From Research and Innovation to Market Deployment: 7-142. Gistrup, Denmark: Rivers Publishers, 2014.

\section{AUTHOR PROFILE}

Norlinda binti Mohd Rozar Currently is a Post Doctoral Researcher, Department of Research and Innovation at University Malaysia Kelantan, Malaysia. Pursuing research in social entrepreneurship area. Received PhD from University Malaysia Pahang in Engineering Technology. Study about the sustainability in business operations, and the particular expertise in statistical and mathematical analysis.

Mohd Nazri Bin Zakaria Currently is the Senior Lecturer and Deputy Dean of Students Development and Entrepreneurship at Faculty of Entrepreneurship and Business at Universiti Malaysia Kelantan. Before joining UMK he was a Senior Industrial Relation Officer at Institute of Labour Market and Information Analysis, Ministry of Human Resources Malaysia. Prior joining ILMIA, he has served as a Assistant Director of Labour for Labour Department of Malaysia from 2001 to 2011. At ILMIA and Labour Department, his responsibilities are monitor research progress appointed consultant and study current need of supply and demand of manpower (ILMIA) and as enforcement officer (Labour Law) for Labour Department of Malaysia.

Muhammad Aslyzan bin Razik Currently working as lecturer at Faculty of Entrepreneurship and Business at Universiti Malaysia Kelantan. He is a part time lecturer for Islamic Management at Open University Malaysia and also a Business area at KFORCE, Malaysia. He is examiner for management and business examination for Private Institutes. He is also conducted a research in entrepreneur for Government Institute.

Aisyah Bahiah Aidul Bahrein, currently is a doctoral student at Faculty of Entrepreneurship and Business at Universiti Malaysia Kelantan.

Saadi bin Ahmad Kamaruddin, Currently a part time lecturer at HELP University. He just finished his doctoral study from Universiti Teknologi MARA, Shah Alam campus on May 2018 in Information Technology and Quantitative Sciences. He is an active researcher in Artificial Neural Network applications field. 